\title{
TEKNIKALISASI PEMETAAN WILAYAH ADAT: KETAHANAN SOSIAL BUDAYA KOMUNITAS ETNIS SUMURI DI KABUPATEN TELUK BINTUNI PROVINSI PAPUA BARAT
}

\author{
I Ngurah Suryawan \\ Jurusan Antropologi Fakultas Sastra dan Budaya Universitas Papua (UNIPA) Papua Barat \\ e-mail:ngurabsuryawan@gmail.com \\ DOI: bttp:/ / dx.doi.org/10.30983/islam_realitas.v2i2.185
}

Diterima: 2 Juli $2016 \quad$ Direvisi : 23 November $2016 \quad$ Diterbitkan: 20 Desember 2016

\begin{abstract}
This article analyzes the impacts of the penetration of investment in Sumuri District, Teluk Bintuni Regency, West Papua Province. One thinsg that the company should do is mapping the rights of indigenous clans to identify areas that became the company's location. At this moment the complexity of problems link the sociocultural community resistance to the host community with the technicalization mapping problem. Territorialising the indigenous territories just happens and local communities trapped in the processes of regulation prepared by the country and the company. The toughest challenge in participatory mapping is clearing the technicalization process and setting that become the perspective of countries and companies. This article tries to explore what happens in negotiations between technicalization processes of mapping indigenous territories with expectations awakened in people Sumuri about socio-cultural changes. In this contestation, the imagination about involving customs and cultures in the current socio-cultural changes and the setting becomes very problematic and risky.
\end{abstract}

Keywords: Technicalization, Mapping, Cultural Territories, Conflicts, Social and Cultural Resilience

\section{Abstrak}

Artikel ini menganalisis dampak-dampak yang ditimbulkan dari penetrasi investasi di Distrik Sumuri Kabupaten Teluk Bintuni Provinsi Papua Barat. Salah satu hal yang dilakukan perusahaan adalah pemetaan hak-hak ulayat marga untuk mengidentifikasi wilayah yang menjadi lokasi perusahaan. Pada moment inilah muncul kompleksitas persoalan yang menghubungkan ketahanan sosial budaya komunitas tempatan dengan teknikalisasi permasalahan pemetaan ini. Teritorialisasi wilayah-wilayah adat terjadi begitu saja dan komunitas tempatan terjebak dalam proses-proses pengaturan yang dipersiapkan oleh negara dan perusahaan. Tantangan terberat pemetaan partisipatif adalah menjernihkan proses teknikalisasi dan pengaturan yang menjadi perspektif dari negara dan perusahaan. Artikel ini mencoba mendalami apa yang terjadi dalam negosiasi antara proses teknikalisasi pemetaan wilayah adat tersebut dengan harapan-harapan yang terbangun dalam diri orang Sumuri tentang perubahan sosial budaya. Dalam kontestasi inilah imajinasi tentang melibatkan adat dan budaya dalam arus perubahan sosial budaya dan pengaturan menjadi sangat problematik dan riskan.

Kata Kunci: Teknikalisasi, Pemetaan, Wilayah Adat, Konflik, Ketahanan Sosial Budaya

\section{Latar Belakang}

Kampung Forada di Distrik Sumuri, Kabupaten Teluk Bintuni, Provinsi Papua Barat adalah kampung heterogen. Kampung ini dikenal dengan Kampung SP (Satuan Pemukiman) untuk para transmigran yang mayoritas berasal dari Jawa dan sebagian dari NTT (Nusa Tenggara Timur) yang menjadi buruh sawit. Tidaklah heran jika kampung ini dianggap sebagai "Kampung SP". Namun, justru di kampung inilah salah satu cikal bakal perseteruan yang melibatkan marga-marga di 
Distrik Sumuri. Pemicunya adalah kahadiran berbagai macam perusahaan dari mulai sawit, kayu, dan tentunya BP/LNG Tanggung perusahaan gas yang menguasai wilayahwailayah adat orang Sumuri. Situasi ini menguntungkan sekaligus mempersulit orang Sumuri untuk memposisikan dirinya. Hak-hak ulayat mereka perlahan namun pasti menjadi bahan negosiasi dari perusahaan-perusahaan yang hadir di kampung mereka. Tak ayal lagi yang terjadi adalah perpecahan luar biasa di internal-internal marga untuk berusaha menegosiasikan hak ulayat mereka (baca: diri dan identitas mereka) dengan dunia global yang diwakili oleh perusahaan-perusahaan dengan berbagai implikasinya.

Pemetaan wilayah adat hadir untuk memberikan kesan "partisipatif" ketika seluruh komunitas adat dengan berbagai margamarganya diundang hadir untuk mendeskripsikan sejarah dan kepemilikan hak ulayat mereka, untuk kemudian dibuatkan peta dan ditarik garis-garis batasnya. Ketika peta wilayah adat selesai di atas kertas bagi perusahaan, tidak demikian dengan masyarakat adat. Mereka secara terus menerus menegosiasikan diri mereka melalui media tanah ulayat yang mereka miliki dengan kepentingan dunia global yang diwakili oleh korporasi. Artikel ini mencoba untuk memahami peta besar pemetaan wilayah yang menjamur dengan basis argumentasi seperti yang diungkapkan ole $\mathrm{Li}$ tentang teknikalisasi kompleksitas persoalan di masyarakat "hanya" dengan merumuskan indikator-indikator masalah dan pemecahan (baca: hal teknis) tanpa menyentuh persoalan dasarnya yaitu: kekuasaan atau dalam wacana yang lebih besar adalah kolonisasi itu sendiri ${ }^{1}$.

${ }^{1} \mathrm{Li}$, Tania Murai, Will to Improve, Perencanaan, Kekuasaan, dan Pembangunan di Indonesia (terj. Hery Santoso dan Pudjo Semedi), (Jakarta: Marjin Kiri, 2012), h. 13.
Artikel ini menelusuri jejak-jejak cacat dari pelaksanaan pemetaan hak ulayat yang berlangsung di salah satu kampung yang melibatkan marga Bayuni yaitu salah satu marga dari orang Sumuri. Bagian pertama dari artikel ini akan memberikan konteks lokal dimana pertentangan mengenai batas hak ulayat antara marga Bayuni dan Ateta itu terjadi yaitu di Kampung Forada. Bagian berikutnya mencoba menelusuri hadirnya korporasi di Distrik Sumuri untuk memberikan latar belakang situasi terjepit yang dialami oleh Sumuri dalam merespon perubahan yang perlahan namun pasti akan terjadi. Bagian berikutnya mendalami tentang pengakuan (claim) marga Bayuni mengenai hak ulayat dan perjalanan nenek moyang terhadap lokasi-lokasi penting yang digunakan oleh perusahaan (dalam hal ini Genting Oil). Bagian terakhir mencoba merefleksikan program pemetaan hak-hak ulayat serta pembangunan secara umum yang belum menyentuh kesadaran inisiatif perubahan di tengah masyarakat. Yang terjadi adalah pengulangan sistem pembangunan sebagai sebuah "proyek" dengan aturan-aturan baku dalam mengidentifikasi masalah dan merumuskan pemecahannya.

\section{Forada Dan Ketahanan Sosial Masyarakat} Adat

Masyarakat adat Papua merupakan satu dari teritor masyarakat adat di dunia yang tengah bergumul dalam menghadapi perubahan dan modernisasi. Masuknya pengaruh asing bahkan penguasaan negara dan incaran koorporasi terhadap wilayan dan budaya mereka tengah menjadi studi menarik para peneliti seperti Lamont ${ }^{2}$, Coakley ${ }^{3}$, dan

${ }^{2}$ Lamont, Michèle, ed. The Cultural Territories of Race: Black and White Boundaries (Chicago: University of Chicago Press, 1999), h. 30

3 Coakley, John, "National Territories and Cultural Frontiers: Conflicts of Principle in The Formation of States in Europe", West European Politics, Vol. 5, No. 4, 1982, h. 34-49 
Raffan ${ }^{4}$. Studi Sukada telah menjelaskan bahwa Kampung Forada kini bisa disebut sebagai salah satu kampung migran terbesar selain Kampung Materabu Jaya, kampung sebelumnya di Distrik Sumuri Kabupaten Teluk Bintuni ${ }^{5}$. Sebagai kampung yang dihuni oleh sebagaian peserta transmigrasi, pemukiman yang mereka tempati hanya di pinggiran jalan Tofoi (sebagai ibukota distrik) menuju Saengga dan Tanah Merah Baru (lokasi ekslusif BP/LNG Tangguh). Di tengah jauh ke dalam dari jalan utama itulah tanahtanah layat yang masih tersisa dari marga Bayuni dan Ateta yang saling bersilangan. Sebelumnya mereka hidup tenang-tenang saja, tapi mendadak bersitegang seketika saat perusahaan Genting Oil masuk ingin melakukan pengeboran di lokasi yang diidentifikasi mengandung sumber minyak tersebut. Ujung-ujungnya sudah bisa ditebak yaitu uang atau dalam bahasa orang Sumuri disebut dengan Sene.

Awal berdirinya Kampung Forada sebenarnya berawal dari pengembangan kampung di Tofoi dan derasnya arus migrasi ke Sumuri. Lahirnya Kampung Forada tidak bisa dilepaskan dari sosok seorang David Simuna. Paitua (bapak) inilah yang terkenal sebagai bapak pemekaran kampong-kampung di Distrik Sumuri Kabupaten Teluk Bintuni. David Simuna pernah menjabat sebagai kepala kampong Tofoi, Saengga, dan menjadi orang yang membidani kelahiran kampong-kampung baru di daerah SP (Sentra Pemukiman) para transmigran di Distrik Sumuri.

Awalnya bermula dari tahun 1977 ketika itu David Simuna kembali ke Bintuni setelah

${ }^{4}$ Raffan, James, Frontier, Homeland and Sacred Space: A Collaborative Investigation into Cross-Cultural Perceptions of Place in the Thelon Game Sanctuary (USA: Northwest Territories, 1992), h. 50.

${ }^{5}$ Sukada, Soni dkk, "Pemetaan Hak-Hak Ulayat Orang Sumuri di Distrik Sumuri Kabupaten Teluk Bintuni”, Laporan Penelitian, Universitas Negeri Manokwari, Papua Barat, 2015, h. 20 sekian lama merantau di Jayapura. Ia juga termasuk menjadi Tim 9 yang salah satunya menjadi cikal bakal dari terbentuknya Kabupaten Teluk Bintuni. Sejak menginjakkan kaki di Teluk Bintuni sebagai tanah kelahirannya, David Simuna kemudian berkiprah untuk membentuk kampongkampung (dulu namanya desa-desa) yang berada di wilayah transmigrasi yaitu SP (Sentra Pemukiman). David Simuna juga menjadi saksi bagaimana masuknya transmigrasi dan perusahaan-perusahaan besar di daerah Sumuri. Salah satunya adalah kehadiran BP (British Petrolium) yang banyak mengubah masyarakat di Sumuri selain tentunya kehadiran para transmigran.

Pada saat datang pertama ke Tofoi, ia mengetahui dengan jelas bahwa marga Simuna dan Soway sudah "menjual putus" (menjual tanah dengan sekali bayar) semua tanah ulayatnya kepada BP. Lokasi itulah kini yang menjadi lokasi perusahaan yang sebelumnya adalah tanah ulayat milik dari marga Simuna dan Soway. Sebelumnya Tofoi tidak maju seperti sekarang. Hadirnya perusahaan kayu Jayanti yang membuat mess di Tofoi membuat daerah ini berkembang pesat. Di daerah pesisir, Tofoi, atau sebelumnya dinamakan "Kelapa Dua" adalah desa induk yang kemudian berkembang menjadi kampungkampung baru. Pada saat perusahaan kayu Jayanti masuk di tahun 1999, David Simuna menjadi salah satu tokoh masyarakat yang bekerja sebagai Kepala Humas (hubungan masyarakat) di perusahaan Jayanti.

David Simuna sebelumnya adalah seorang guru yang telah melanglang buana dari mulai di pedalaman Teluk Bintuni hingga kemudian berakhir di Jayapura. Dia adalah lulusan ODO Fakfak yang memulai petualangannya sebagai guru di pedalaman kampong-kampung di Teluk Bintuni. Ia kemudian melanjutkan studinya di sekolah guru di Serui dan Jayapura. Ia juga pernah 
berpengalaman membawa kapal laut Dwi Warna yang berlayar hingga sampai ke PNG (Papua New Guinea).

Ketika kembali ke Bintuni, ia sudah menginjak tua dan menghabiskan masa pensiunnya dengan bekerja sebagai Kepala Humas Perusahaan Jayanti dan membuka kampung-kampung baru di lokasi transmigran. Kini ia adalah kepala kampong Forada. Kampung Forada sendiri sebenarnaya adalah tanah milik dari marga Bayuni, pada saat ini laki-laki tertua di marga tersebut adalah Yosephus Bayuni. Penduduk "asli" yang tinggal di Kampung Forada sekarang adalah David Simuna dan anak-anaknya sekarang yang berjumlah 4 KK (Kepala Keluarga) dan dari Yosephus Bayuni yaitu $3 \mathrm{KK}$ sendiri juga mempunyai rumah di Forada dan juga di Tofoi. David Simuna dan Yosephus Bayuni mempunyai hubungan kekerabatan yang dekat karena mama dari Yosephus Bayuni adalah dari Simuna. Jumlah KK yang berada di Kampung Forada adalah 435 KK 1284 jiwa yang didominasi oleh para transmigran yang datang ke Sumuri. Kampung lainnya yang juga didominasi oleh para transmigran adalah Kampung Materabu Jaya.

Gambar 1. David Simuna memberikan penjelasan

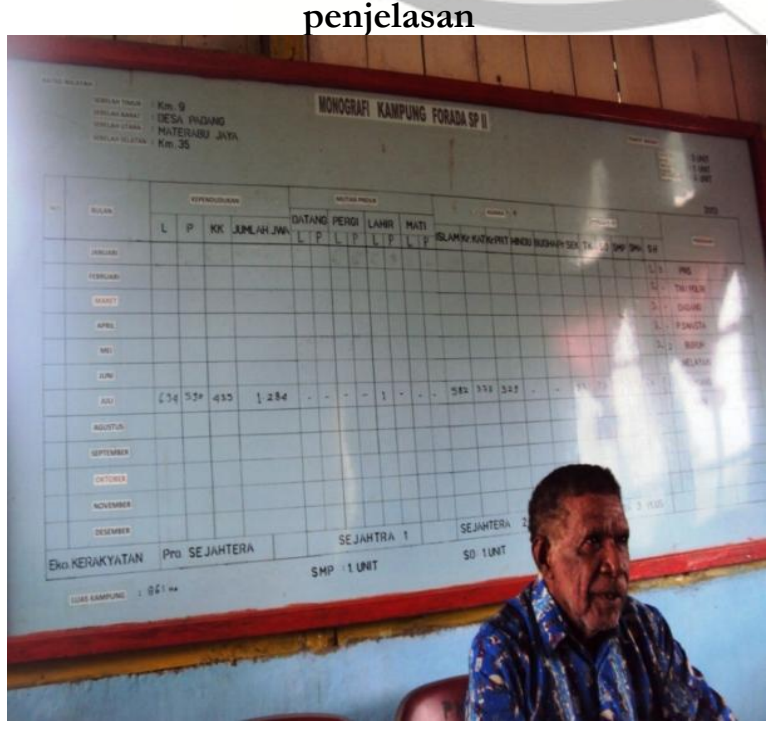

(foto: I Ngurah Suryawan)
Kampung Forada berbatasan dengan Km 9 wilayah sawit Varita (timur), padang Agoda (barat), Kampung Materabu Jaya (utara) dan $\mathrm{Km} 35$ wilayah sawit Varita (selatan). Dengan wilayah batas-batas tersebut, David Simuna mengungkapkan bahwa perselisihan antara Bayuni dan Ateta tentang sumur RIG Forada tidak perlu terjadi jika kedua marga mengerti tentang batas masingmasing marga. Jika mau jujur, menurut David Simuna sumur RIG Forada itu adalah hak dari Bayuni, namun ia sangat menyesalkan juga Yosephus Bayuni yang dipanggilnya sebagai adik tidak bekerjasama dengannya untuk memperkuat status sumur RIG Forada itu. Sehingga ia tidak bisa berbuat lebih jauh. Yang terjadi justru marga Bayuni itu bekerjasama dengan Inanosa untuk melawan Ateta. Sementara marga Ateta tetap melawan bahwa mereka juga mempunyai hak atas RIG Forada.

\section{Gambar 2. Balai Kampung Forada SP 2}

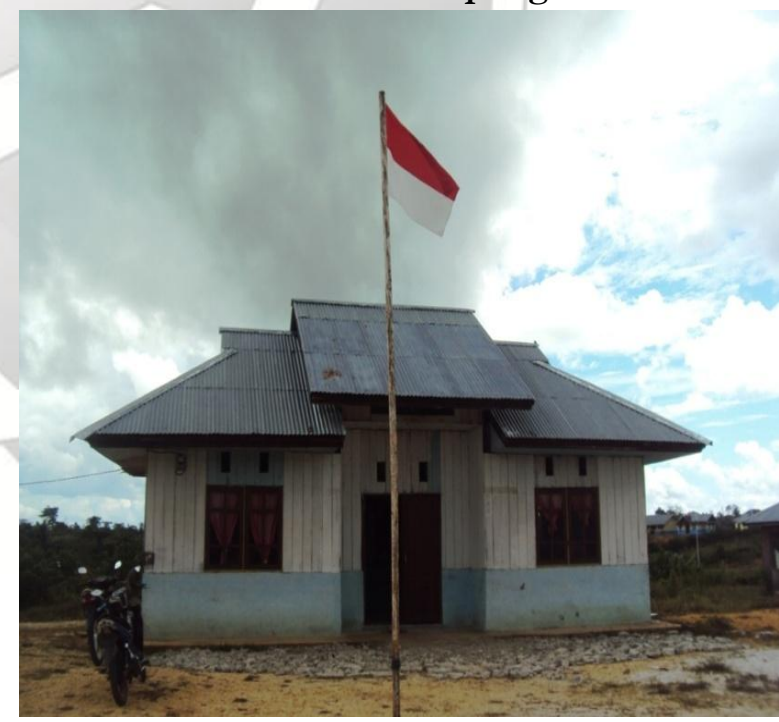

(foto: I Ngurah Suryawan)

Perkampungan Forada SP 2 memang didominasi oleh para pendatang yang bertransmigran di Sumuri. Diantara mereka adalah masyarakat dari Jawa yang mendominasi rumah-rumah di pinggir jalan Kampung Forada. Sementara masyarakat dari NT'T (Nusa Tenggara Timor) memiliki perkampungan tersendiri di dalam wilayah 
kampung Forada. Sebagian besar diantara mereka adalah pegawai kelapa sawit Varita dan ada juga yang membuka usaha-usaha seperti kios-kios toko kelontong yang banyak sekali ditemui di wilayah kampung SP baik itu Materabu Jaya maupun Forada.

\section{Sumuri dan Interkoneksi serta Pemberdayaan Masyarakat}

Pemberdayaan masyarakat adat merupakan salah satu solusi jalan tengah ketika negara atau korporasi ingin menegosiasikan wilayah adat untuk dijadikan eksploitasi industri mereka sebagaimana penelitian Andayani' ${ }^{6}$ dan Safa'at? .

Jika melihat perkembangan Sumuri, maka interkoneksi dengan dunia global tak terhindarkan. Masuknya korporasi ke Sumuri memiliki sejarah yang panjang. Tahun 1982 beroperasi perusahaan HPH/IUPHHK PT. Agoda Wahitam yang membuka kamp di sekitar Tofoi (Lama). Penduduk yang semula bermigrasi ke Saengga pindah kembali ke Tofoi untuk mendapatkan pekerjaan dari kehadiran perusahaan. Tetapi HPH/IUPHHK PT. Agoda Wahitam gagal beroperasi karena alat berat mereka tenggelam di sungai Senendara. Pada tahun 1986 HPH/IUPHHK PT Djayanti Group membuka kamp di Kelapa Dua atau Imuri. Secara berangsur angsur penduduk Tofoi pindah ke Kelapa Dua/Imuri untuk mendapatkan pekerjaan hingga akhirnya Tofoi (lama) ditinggalkan oleh penduduk. Bila ditanya oleh pendatang, penduduk tempatan (indiginous) yang pindah ke Kelapa Dua/Imuri

\footnotetext{
${ }^{6}$ Andayani, Anak Agung Istri, Edhi Martono, and Muhamad Muhamad, "Pemberdayaan Masyarakat Melalui Pengembangan Desa Wisata Dan Implikasinya Terhadap Ketahanan Sosial Budaya Wilayah (Studi Di Desa Wisata Penglipuran Bali.", Jurnal Ketahanan Nasional, 23.1 2015, h. 1-16

7 Safa'at, Rachmad, "Rekonstruksi Politik Hukum Ketahanan Pangan Berbasis Pada Sistem Kearifan Lokal (Studi Kasus Dinamika Perlindungan Hukum Hak Masyarakat Adat Tengger Dalam Menuju Kedaulatan Pangan)", Disertasi Program Pascasarjana Undip, 2011, 16
}

mengatakan mereka adalah orang Tofoi secara perlahan nama Kelapa Dua/Imuri bergeser menjadi Tofoi. Pada akhirnya nama Kelapa Dua berganti menjadi Tofoi hingga saat ini. Beroperasinya HPH/IUPHHK PT. Djayanti di Kelapa Dua / Tofoi mendorong penduduk asli dari Tanah Merah dan Saengga pindah ke Kelapa Dua (Tofoi). Setelah PT. Djayanti selesai beroperasi banyak tenaga kerja eks Djayanti dari luar daerah memilih menetap di Tofoi, sehingga Tofoi menjadi perkampungan besar yang dihuni oleh penduduk dari berbagai daerah di Indonesia.

Pada awal 1990-an beroperasi perusahaan sawit PT. Varita Maju Tama di lokasi eks konsesi PT. Djayanti Group. Untuk mendukung perkebunan sawit ini pemerintah mendatangkan transmigran dan membentuk Satuan Pemukiman di Materabu (SP1) dan Forada (SP2). Kedua Satuan Pemukiman (SP) ini merupakan bagian dari kampung (desa) Tofoi. Tahun 1999 PT. Varita Maju Tama membangun sebanyak 60 buah rumah untuk transmigran lainnya di Agoda. Tetapi transmigran asal luar Papua batal didatangkan dikarenakan jatuhnya rezim Orde Baru, sehingga perumahan di Agoda terbengkalai. Baru pada tahun 2003 beberapa penduduk Tofoi khususnya marga Ateta sebagai pemilik ulayat wilayah Agoda menempati rumahrumah tersebut.

Tahun 1992, dua orang marga Soway dari Tanah Merah mendirikan rumah di Onar dengan tujuan menjaga tanah milik marga Agofa dari penyerobotan pihak luar karena lokasinya berbatasan wilayah Fak Fak yang didiami oleh Suku lain. Tahun 1995 beroperasi perusahaan yang melakukan kegiatan reboisasi dengan membawa tenaga kerja dari kampung sekitar penduduk luar. Setelah kegiatan reboisasi selesai beberapa tenaga kerja memutuskan untuk menetap di Onar. Selanjutnya berdatangan pula para nelayan dari Seram Maluku dan Bugis berdiam di Onar. 
Sejak masa itu di Onar berdiri pemukiman penduduk. Onar saat itu merupakan bagian dari Kampung Saengga.

Tahun 2005 penduduk Tanah Merah di relokasi karena lokasi tersebut akan digunakan untuk kepentingan proyek pengembangan LNG Tangguh. LNG Tangguh membeli tanah dari marga Simuna di sekitar muara Sungai Saengga untuk memukimkan kembali penduduk asal Tanah Merah. Kawasan relokasi ini kemudian dikenal dengan nama Kampung Tanah Merah Baru. Sebagian penduduk Tanah Merah khusunya marga Agofa dan Soway memilih di relokasi ke Onar karena Onar merupakan tanah ulayat marga Agofa. Untuk kepentingan tersebut LNG Tangguh membebaskan tanah seluas 32 ha di Onar untuk memindahkan penduduk asal Tanah Merah. LNG Tangguh membangun 29 unit rumah di Onar yang kemudian dikenal dengan nama Onar Baru. Untuk menghindari kecemburuan sosial penduduk Saengga terhadap penduduk Tanah Merah Baru yang dibangunkan rumah baru dengan fasilitas lengkap, LNG Tangguh juga merenovasi rumah-rumah penduduk Saengga sama persis seperti rumah penduduk Tanah Merah yang di relokasi ke Tanah Merah Baru. Dengan demikian terdapat 3 kelompok pemukiman yang dibangun oleh LNG tangguh yaitu Tanah Merah Baru, Onar Baru dan Saengga. Rumahrumah ini hampir serupa dengan rumah yang dibangun oleh PT. Freeport Indonesia untuk suku Amungme di Kabupaten Mimika Papua.

Hingga tahun 2005 wilayah Sumuri masih merupakan bagian dari Distrik Babo. Tahun 2006, Sumuri diresmikan menjadi distrik tersendiri yang terdiri dari 5 kampung definitif yaitu Tofoi sebagai ibukota distrik, Materabu Jaya (SP1), Forada (SP2), Saengga dan Tanah Merah Baru. Sedangkan tiga kampung lainnya yaitu Onar Lama, Onar Baru dan Agoda merupakan kampung pemekaran yang belum definitif. Hingga tahun 2015, ketiga kampung pemekaran belum tercantum dalam data BPS Kabupaten Teluk Bintuni.

Pada tahun 2013 Pemda Teluk Bintuni menetapkan lokasi tempat LNG Tangguh dan sekitarnya sebagai Kawasan Ekonomi Khusus (KEK) dengan pengembangan seimbang antara wilayah Utara dan Selatan. Berdasarkan SK Bupati Teluk Bintuni No. 76/01/BUPTB/V/2013, Kampung Onar Distrik Sumuri ditetapkan sebagai lokasi pendirian pabrik petrokimia dengan investor utama Ferrostaal $\mathrm{GmbH}$, Jerman. Untuk mendukung proyek ini akan ada pengerahan tenaga kerja sebanyak 3000 orang baik karyawan langsung dan tidak langsung. Hal ini berarti ke depan akan terjadi gelombang migrasi yang cukup besar ke Distrik Sumuri. $^{8}$

\section{Bayuni dan Sumur Bor}

Sejarah marga Bayuni bersumber dari seorang lelaki yang menjadi tetua dari Bayuni yang bernama Yosephus Bayuni. Bayuni dalam bahasa Sumuri Bu memiliki arti "ko pergi" (kamu pergi). Jika melihat dari sejarah, Yosephus Bayuni sebenarnya berasal dari marga Wayuri (pihak mama) dan Simuna (dari bapak). Namun diangkat anak oleh pemilih dusun pala yang bermarga Bayuni dan dipermandikan (dibaptis) sebagai marga Bayuni (silsilah marga Bayuni terlampir).

Sejarah awalnya dari perjalanan marga Bayuni adalah ketika pada tahun 1972-1973 terjadi perpindahan beberapa marga dari Tofoi (ibukota Distrik Sumuri) menunggu Saengga. Beberapa marga yang masuk dalam perpindahan tersebut adalah marga Ateta, Inanosa, Simuna, Dolisara dan Wamay). Pada saat itu bertepatan dengan masuknya Perusahaan Agoda Waitam yang membeli saham dari Perusahaan Jayanti. Perusahaan inilah yang kemudian membuka jalan dan

${ }^{8}$ Tim LPM UI, "Pemetaan Sosial Masyarakat Distrik Sumuri Kabupaten Teluk Bintuni”, Laporan Penelitian, Lembaga Pengabdian Masyarakat Universitas Indonesia, 2014, h. 64 
menerima tenaga kerja dari masyarakat Sumuri.

Kampung Forada sendiri berawal dari hadirnya Perusahaan Sawit Varita yang memiliki wilayah sekitar SP (Satuan Pemukiman) transmigran yaitu SP 1 - SP 2 adalah penduduk transmigran yang berasal dari Jawa. Penduduk ini awalnya bergabung bersama-sama di Tofoi. Namun, dengan hadirnya perusahaan kemudian penduduk ini kemudian bermigrasi (berpindah) ke kampungkampung baru yang masih berada di wilayah sekitar perusahaan. Oleh sebab itulah dibentuk kampong-kampung baru yang merupakan pembagian dari dua wilayah SP yaitu SP 1 menjadi Kampung Materabu Jaya dan SP 2 menjadi Kampung Forada. Terpilih sebagai kepala kampong Forada adalah David Simuna yang sebelumnya adalah kepala kampong Saengga dan berjasa besar dalam pemekaranpemekaran kampong di Distrik Sumuri'

Sejarah marga Bayuni sebenarnya adalah berawal dari seorang moyang yang mempunyai batu yang berasal dari Sorompia Wiria, sebuah danau dari daerah Fakfak. Lokasi itu berasal dari Sungai Nusuk, yang bisa menggunakan long boat menuju ke sungai tersebut. Moyang inilah yang kemudian membuka jalan untuk mereka bisa tinggal di daerah Tomage. Nama moyang dari marga Bayuni sendiri yang berasal dari Tofoi adalah Amuri. Moyang inilah yang melakukan hongi (perang) untuk memperebutkan pohon damar dan pala. Perjalanan panjang moyang ini dengan baku hongi (saling berperang) membawa mereka akhirnya tinggal di Dusun Sagu Waisnabu.

${ }^{9}$ Sukada, Soni dkk, "Pemetaan Hak-Hak Ulayat Orang Sumuri di Distrik Sumuri Kabupaten Teluk Bintuni. h. 54
Gambar 3. Yosephus Bayuni Menunjukkan Sejarah Wilayah-wilayah Adat Marga Bayuni

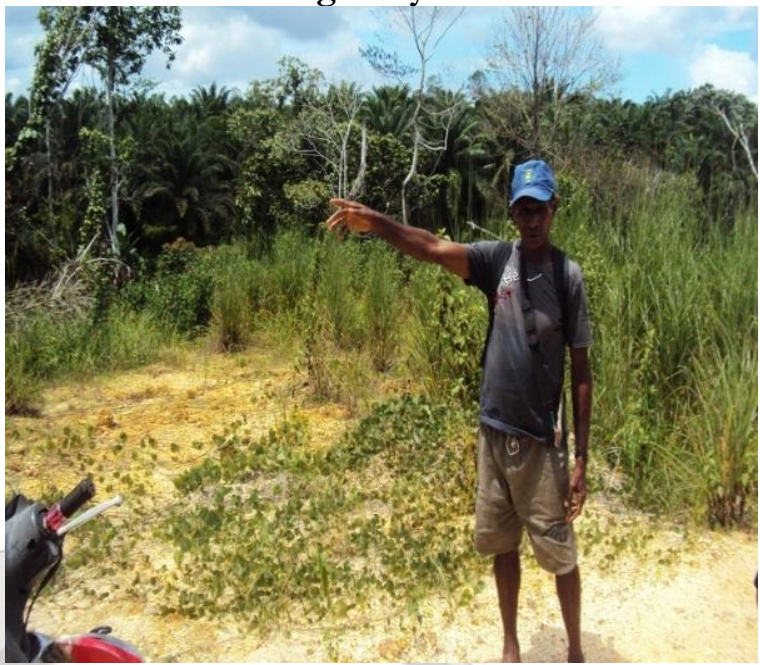

(foto: I Ngurah Suryawan)

Moyang Bayuni yang bersama Amuri inilah yang kemudian tinggal dan menetap di Waisnabu dan menjadikan batu gosok sebagai ciri saat tinggal di tempat ini. Di lokasi inilah Frans Bayuni yang merupakan ayah angkat dari Yosephus Bayuni pernah tinggal di tempat ini dengan mencari burung kuning hingga ke arah hutan di padang. Di lokasi hutan inilah terdapat juga waga-waga (hutan bambu) yang juga menjadi ciri dari perjalanan moyang dari Amuri. Selain itu dusun pala yang berada di lokasi hutan itu juga menjadi lokasi dari migrasi (perjalanan) dari moyang Amuri. Beberapa keturunan dari marga Bayuni mengambil pala di lokasi tersebut untuk dijual kepada pedagang dari Cina. Marga-marga lainnya yang juga berbatasan dengan dusun pala tersebut seperti Ateta, Inanosa, Siwana, Dolisara, dan Wamay sudah mengetahui bahwa dusun pala tersebut adalah milik dari Bayuni. Moyang Amuri menamakan tempat itu Kigurusu yang berarti hutan rimba yang orang lain tidak pernah datang sebelumnya. Namun moyang-moyang beberapa marga yang ada di Sumuri sudah pernah datang ke lokasi tersebut untuk mencari pala alam kemudian dijual untuk memenuhi kebutuhan hidup sehari-hari. 
Perjalanan moyang Bayuni yaitu Amuri dengan demikian dimulai dengan menyisiri hutan-hutan yang berada di wilayah pesisir Sumuri hingga kemudian untuk pertama kalinya singgah dan menetap sementara di Tomage. Setelah menetap beberapa lama di Tomage, kemudian mereka bermigrasi dengan melewati padang rumput luas yaitu Padang Agoda yang mulai untuk menemukan mata pencaharian dengan menggosok-gosok kayu agatis yang kemudian bisa dijual kepada para pedagang Cina yang sudah menunggu di laut. Awal mulanya moyang Bayuni melihat kayu agatis adalah keheranan mereka melihatan jenis kayu yang bersih lalu kemudian menyapu-nyapunya yang semakin melihat kayu itu bersih. Karena keheranan itulah mereka kemudian menggosok-gosok kayu tersebut dan ternyata menjadi kayu yang menyambung kehidupan mereka.

Perjalanan moyang Bayuni dilanjutkan melalui Padang Agoda yang kemudian memutuskan untuk menetap sementara di Dusun sagu Waesnabu yang berarti batu gosok. Para moyang Bayuni ini sangat membutuhkan tempat-tempat untuk sumber kehidupan. Pada saat itu yang menjadi bahan makanan pokok adalah sagu, sehingga dusun-dusun sagu menjadi tempat persinggahan para moyangmoyang beberapa marga di Sumuri. Dusundusun kecil inilah yang disebut dengan dusun sagu yang menjadi incaran marga-marga lainnya juga. Dusun-dusun kecil, dusun sagu ini dalam Bahasa Sumuri disebut dengan Bajey, Kebey. Lokasinya adalah di sekitar padang Agoda di wilayah bawah. Di wilayah-wilayah dusun sagu inilah terjadi persilangan sungaisungai dan dusun sagu yang lain. Di wilayah yang menjadi perjalanan marga Bayuni terdapat juga dusun sagu yaitu Manggosa dan Teganabung yang menjadi lokasi dari marga Morena untuk sumber kehidupan. Di sekitar wilayah itu juga terdapat dua kali (sungai) besar yaitu Kali Kau dan Kali Saengga.
Dusun-dusun sagu dan kali merupakan tempat yang menjadi persilangan wilayah masing-masing marga yang berada di Sumuri. Salah satu yang menjadi tempat persilangan tersebut adalah Kali Wano yang merupakan persilangan antara marga Ateta dan Inanosa. Persilangan sungai inilah yang juga menjadi migrasi (perjalanan) dari moyang Bayuni. Awalnya adalah moyang Ateta dan Morena hidup bersama dengan pangkur sagu (mengolah sagu menjadi makanan dari pohonnya). Intinya adalah mereka ini (Ateta dan Morena) "makan bersama". Namun ketika perusahaan (sawit) datang yang kemudian memilah-milah wilayah marga-marga tersebut sehingga ada keinginan untuk memanipulasi/menipu cerita dan mengambil hak orang lain.

Pada prinsipnya, dengan perjalanan marga-marga yang ada di wilayah Sumuri, wilayah-wilayah adat mereka sebenarnya saling baku sambung (sambung-menyambung) karena perjalanan moyang yang memang bersamasama untuk mencari tempat penghidupan, yang pada masa itu terletak di dusun sagu dan dusun pala. Namun ketika perjalanan berlangsung masing-masing marga saling adu kekuatan sehingga yang lemah tidak bias bertindak dan melepas saja wilayah adat mereka ${ }^{10}$.

Pada masing-masing marga ketika bersama-sama tinggal untuk memangkur/menokok sagu (mengolah sagu menjadi makanan dari pohonnya) telah menetapkan batas-batas wilayah mereka masing-masing. Seperti misalnya batas antara marga Bayuni dengan marga Ateta adalah kali bambu yang menjadi milik dari marga Ateta dan dusun sagu Waesnabu menjadi milik dari Bayuni. Sebenarnya masing-masing marga sudah menetapkan batas wilayah mereka

\footnotetext{
10 Suryawan, I. Ngurah, "Di Antara Ugatamee dan Injil: Transformasi Teologi-Teologi Pribumi di Tanah Papua", Islam Realitas: Journal of Islamic \& Social Studies, Vol. 2, No.1, Januari-Juni 2016, h. 63-69.
} 
masing-masing yang diceritakan secara turuntemurun dari moyang-moyang mereka sebelumnya. Para moyang inilah yang sebenarnya memutuskan batas-batas wilayah masing-masing marga. Namun dalam perkembangannya batas-batas tersebut akhirnya berubah karena keinginan untuk menguasai satu wilayah yang dianggap menguntungkan dan menghasilkan uang karena hadirnya perusahaan.

Seperti misalnya yang terjadi antara marga Bayuni dan Ateta. Saat perusahaan masuk, masing-masing marga mempertahankan prinsipnya dengan mengatakan batas-batas wilayah mereka masing-masing. Batas-batas yang mereka sebutkan itulah yang kemudian menabrak wilayah marga yang lain. Masing-masing tahan prinsipnya sehingga akhirnya saling baku tumbuk (bentrok fisik). Oleh sebab itulah masing-masing marga cukup hanya mengatur wilayahnya saja, jangan sampai mengatur wilayah marga yang lain.

Wilayah yang menjadi perebutan antara Bayuni dan Ateta adalah yang berada di kawasan SP 1 dan SP 2 yaitu RIG 60 (pengeboran minyak). Perselisihan terjadi antara marga Ateta dan Bayuni terkait dengan dusun pala yang diakui oleh marga Bayuni sebagai miliknya. Marga-marga seperti Wamay, Inanosa, Dolisara, Simuna, dan Morena semua mengetahui bahwa dusun pala yang menjadi lokasi RIG 60 adalah milik dari Bayuni. Saat Frans Bayuni, ayah angkat dari Yosephus Bayuni masih hidup, sering mengajak Yosephus Bayuni untuk mencari pala di dusun pala tersebut. Sampai kemudian SP 1 dan SP 2 dibuka, para transmigran itu semuanya tinggal di wilayah marga Bayuni.

Namun, marga Ateta juga mengakui bahwa dusun pala yang sekarang menjadi lokasi RIG 60 menjadi wilayah mereka. Disinilah pangkal persoalan muncul. Dulu para moyang mereka (Bayuni dan Ateta) makan sama-sama dan bagi dua hasil dari menokok sagu dan mencari pala, namun kini terjadi perselisihan diantara mereka. Oleh sebab perselisihan itulah, pihak perusahaan akhirnya membayar kedua marga masingmasing Rp.100 juta dan keduanya membuat adat sebagai bukti bahwa mereka yang mempunyai tanah adat tersebut. Namun, saat keduanya membuat adat dengan memotong binatang, RIG 60 tidak mendatangkan hasil.

Kisruh antara korporasi dan masyarakat adat tentang penguasaan lahan, satu sisi bisa dikatakan ketidaksiapan sosial masyarakat adat menerima pengaruh, kalau seandainya masyarakat menyadari aspek positif tentu mereka menerima. Di sini penting membangun ketahanan sosial masyarakat sebagaimana Marshall ${ }^{11}$, Adger ${ }^{12}$, dan Magis ${ }^{13}$ bahwa ketahanan sosial masyarakat terutama masyarakat marginal perlu dibangun sehingga dampak negatif modernitas bisa mereka redam dengan kearifan lokal mereka.

\section{Teknikalisasi Pemetaan}

Beroperasinya perusahaan di Distrik Sumuri yang menggunakan tanah adat menjadikan tanah memiliki nilai ekonomi tinggi. Berdasarkan Perdasus No. 22 tahun 2008 dan Perdasus No.23 tahun 2008, setiap perusahaan yang beroperasi di wilayah hukum adat harus menghormati hak hak masyarakat hukum adat atas tanah adat yang dimilikinya. Perusahaan wajib memberikan kompensasi atas tanah adat yang digunakannya. Karena nilai ekonomi tanah inilah, saat ini tanah dan

11 Marshall, Nadine, and Paul Marshall, "Conceptualizing and Operationalizing Social Resilience Within Commercial Fisheries in Northern Australia", Ecology and Society, Vol.12, No.1, 2007, h. 20

12 Adger, W. Neil, et al., "Migration, Remittances, Livelihood Trajectories, and Social Resilience", AMBIO: A Journal of the Human Environment, 31.4. 2002, h. 358-366

${ }^{13}$ Magis, Kristen, "Community Resilience: An Indicator of Social Sustainability", Society and Natural Resources, 23.5. 2010, h. 401-416. 
batas ulayat tanah adat menjadi sangat sensitif dan menjadi sumber konflik antar marga.

Salah satu konflik pemetaan hak ulayat yang terjadi adalah antara Ateta dan Bayuni di Forada. Menurut Marga Ateta bila dilihat dari sejarah asal usul kepemilikan tanah, Blok Forada adalah tanah adat marga Ateta. Kelompok marga Ateta tertentu tidak mengakui adanya tanah adat milik Bayuni. Menurut kelompok Ateta ini Bayuni pada mulanya adalah anak angkat dari Ateta yang diberikan dusun di wilayah tersebut oleh Ateta sebagai tempat untuk "mencari". Maka tanah tersebut tetap merupakan milik Ateta. Di pihak lain Bayuni mengatakan memang benar bahwa nenek moyang Bayuni tinggal bersama dengan Ateta. Tetapi Bayuni memiliki wilayah tanah adat sendiri yang berbeda dengan Ateta. Wilayah tanah adat bayuni berada di Forada yang berbatasan dengan tanah adat marga Ateta dan Inanosa. Forada. Bayuni menolak pendapat bahwa wilayah Forada merupakan pemberian dari Ateta. Sempat terjadi ketegangan antara Bayuni dengan Ateta memperebutkan uang kompensasi dari perusahaan. Konflik mereda setelah kompensasi diberikan kepada kedua belah pihak. Kedua pihak juga dipersilahkan melakukan ritual adat bersama di lokasi sumur Forada. Ritual adat merupakan syarat wajib yang harus dilaksanakan oleh perusahaan sebelum melakukan kegiatan operasional. ${ }^{14}$

Mengacu kepada ide Li di atastentang teknikalisasi (mentekniskan) secara macam persoalan yang terjadi di tengah masyarakat sehingga dengan gampang dicarikan solusinya, persoalan pemetaan hak ulayat menjadi semakin rumit. Rumitnya karena tidak benarbenar mampu untuk menjawab proses transformasi sosial yang terjadi di tengah masyarakat. Pragmatisme untuk kepentingan

14 Sukada, Soni, Haryono, "Pemetaan HakHak Ulayat Orang Sumuri di Distrik Sumuri Kabupaten Teluk Bintuni....., h. 30 . korporasi dan meninggalkan benih konflik sangat terasa dari kerja-kerja pemetaan wilayah adat. Belum lagi dengan tambahan partisipatif untuk menunjukkan keterlibatan aktif masyarakat di dalamnya.

Penyusunan rencana pemetaan wilayah adat menurut Pramono berkembang pesat dengan berbagai kalkulasi-kalkulasi teknis di dalamnya. Ciri utama penyusunan rencana adalah adanya keharusan untuk merumuskan permasalahan dalam istilah-istilah yang bisa melahirkan solusi-solusi teknis ${ }^{15}$. Seorang perencana harus bisa menyaring proses-proses yang tidak terkendalikan guna membentuk suatu arena intervensi di mana berbagai kalkulasi dapat diterapkan. Dengan sengaja para perencana hanya mengangkat sejumlah masalah tertentu dan mengabaikan masalah lainnya. Di bawah tekanan untuk menghasilkan rencana yang lebih baik, seorang perencana tidak berada pada kedudukan untuk menjadikan perencanaan tersebut sebagai obyek analisa ${ }^{16}$.

Sejujurnya menurut Pramono bahwa program pemetaan wilayah adat memiliki tujuan mulia untuk melibatkan masyarakat dalam mengenali wilayah-wilayah batas mereka ${ }^{17}$. Namun seringkali isu dasar yang melatari pemetaan itu tidak didiagnosis dengan tajam. Padahal menggerakkan masyarakat untuk memetakan wilayahnya sendiri itulah yang terpenting sesuai dengan pendapat Chernovita dalam studinya tentang pentingnya peran serta masyarakat dalam pemetaan wilayah pasca bencana ${ }^{18}$. Apa yang terjadi di

${ }^{15}$ Pramono, Albertus Hadi, "Perlawanan atau Pendisiplinan? Sebuah Refleksi Kritis atas Pemetaan Wilayah Adat", Arsip Digital, 2014, h. 207.

${ }^{16} \mathrm{Li}$, Tania Murai, Will to Improve, Perencanaan, Kekuasaan, dan Pembangunan di Indonesia......, h. 3.

${ }^{17}$ Pramono, Albertus Hadi, "Perlawanan atau Pendisiplinan? Sebuah Refleksi Kritis atas Pemetaan Wilayah Adat......., h. 207.

18 Chernovita, Hanna Prillysca, "Pemetaan Wilayah Risiko Bencana Banjir Kabupaten Kudus Berdasarkan Aspek Ancaman, Kerentanan, dan 
Distrik Sumuri secara gamblang menggambarkan apa yang disebut dengan Tania Li dengan mengutip Foucault disebut dengan "kepengaturan". Kepengaturan adalah "pengarahan perilaku" yakni upaya mengarahkan perilaku manusia dengan serangkaian cara yang telah dikalkulasi sedemikian rupa ${ }^{19}$. Berbeda dengan pendisiplinan yang bertujuan memperbaiki perilaku melalui pengawasan ketat dalam kurungan (penjara, rumah sakit jiwa, sekolah), kepengaturan berkepentingan dengan peningkatan kesejahteraan orang banyak. Tujuannya adalah untuk menjamin "kesejahteraan masyarakat, perbaikan keadaan hidup mereka, peningkatan kemakmuran, usia harapan hidup, kesehatan dst." Untuk mencapai tujuan ini menurut Abdillah dibutuhkan sarana khusus. Pada tingkat masyarakat, tidak mungkin perilaku individu diatur hingga hal-hal kecil ${ }^{20}$. Karena itu, kepengaturan bekerja dengan mengarahkan minat dan membentuk kebiasaan, cita-cita, dan kepercayaan. Kepengaturan membentuk suatu keadaan "yang secara buatan sedemikian teratur sehingga orang didorong oleh kepentingan pribadinya masing-masing akan berbuat seperti apa yang seharusnya mereka perbuat". Persuasi ini bisa dilakukan menurut Deda, berlaku untuk semua kasus masyarakat lokal Papua yang merasa termarginalkan. Misalnya saat penguasa berusaha mendapat persetujuan masyarakat dalam kebijakan terkait mereka. Namun ketika kekuasaan dioperasikan dari jarak jauh, masyarakat tidak selalu sadar bahwa sebenarnya perilaku mereka diatur dan mengapa demikian, oleh karenanya

Kapasitas Berbasis Sistem Informasi Geografis", Disertasi, Program Studi Sistem Informasi FTI-UKSW, 2014

${ }^{19} \mathrm{Li}$, Tania Murai, Will to Improve, Perencanaan, Kekuasaan, dan Pembangunan di Indonesia..., h. 9-10

${ }^{20}$ Abdillah, Yayat, and Muhammad Ramdhan, "Pemetaan Tingkat Kerentanan Pesisir Wilayah Kota Pariaman", Jurnal Fakultas Perikanan dan Ilmu Kelautan Unpad, 2012, h.128-148. persetujuan masyarakat tidak menjadi masalah di $\operatorname{sini}^{21}$.

\section{Kesimpulan}

Fragmentasi yang luar biasa di tengah masyarakat karena pengaruh korporasi berimplikasi serius terhadap ketahanan sosial budaya yang ada. Peneliti berargumentasi salah satu ketahanan sosial budaya yang tercabikcabik karena pengaruh uang dan investasi adalah integrasi dan solidaritas sosial yang telah tumbuh dan berkembang jauh sebelumnya. Komunitas di kampong-kampung yang komunal sangat menjungjung tinggi integrasi (kesatuan) dan solidaritas (kebersamaan) dalam sebuah komunitas. Keseluruhan tata nilai dan gerakan reproduksi kebudayaan tergerak karena adanya integrasi dan solidaritas sosial yang terjalin karena talitemali kekerabatan dan kesamaan pandangan dan praktik kebudayaan.

Kini sebagian pelosok tanah Papua, meski di kampung-kampung, sudah tentu tidak terlalu homogen dibandingkan pada zaman dahulu. Sudah banyak perubahan yang terjadi dan praktis di pelosok manapun di Tanah Papua sudah sangat heterogen. Hadirnya para pendatang yang mengadu nasib di pelosokpelosok Tanah Papua sudah tak terhitung jumlahnya. Belum/lagi sebelumnya program transmigrasi memaparkan keterhubungan Papua dengan dunia dan kebudayaan luar. Nilai-nilai dan norma dalam bentuk integrasi dan solidaritas sosial para pendukungnya pun mulai tergeser, tergugat, dan mengalami perubahan yang tak terhindarkan.

Salah satu penyebab memudarnya integrasi dan solidaritas sosial di tengah masyarakat adalah fragmentasi (keterpecahan)

${ }^{21}$ Deda, Andreas Jefri, and Suriel Semuel Mofu, "Masyarakat Hukum Adat dan Hak Ulayat di Provinsi Papua Barat Sebagai Orang Asli Papua Ditinjau Dari Sisi Adat dan Budaya: Sebuah Kajian Etnografi Kekinian", Jurnal Administrasi Publik, Vol. 11, No. 2, 2014, h. 20. 
pandangan tentang nilai dan norma yang dianut sebelumnya. Hal lainnya sudah barang tentu masuknya pandangan-pandangan baru, dalam hal yang umum disebut modernitas dalam berbagai bentuknya. Hadirnya birokrasi, pemerintahan, program-program pembangunan, dan perusahaan dengan giuran modal investasinya adalah nilai baru yang menawarkan perubahan pola pikir dan praktik kehidupan kebudayaan. Solidaritas dan integrasi sosial adalah modal yang tak ternilai harganya untuk menjadikan komunitas masyarakat yang kuat dan mengambil peran dalam perubahan sosial yang terjadi. Perannya adalah sebagai subyek, pelaku dan inisiator dari perubahan itu, bukannya sebagai obyek apalagi sebagai penontonnya. Solidaritas dan integrasi sosial di tengah masyarakat itu layaknya spirit, semangat berkomunitas sosial untuk menghadapi berbagai persoalan dan permasalahan yang terjadi di tengah komunitas tersebut.

\section{Daftar Pustaka}

\section{Buku Teks}

Lamont, Michèle, ed., The Cultural Territories of Race: Black and White Boundaries (Chicago: University of Chicago Press, 1999).

Li, Tania Murai, Will to Improve, Perencanaan, Kekuasaan, dan Pembangunan di Indonesia (terj. Hery Santoso dan Pudjo Semedi), (Jakarta: Marjin Kiri, 2012).

Raffan, James, Frontier, Homeland and Sacred Space: A Collaborative Investigation into Cross-Cultural Perceptions of Place in the Thelon Game Sanctuary, (Northwest: Territories Publish, 1992).

\section{Jurnal dan Laporan}

Abdillah, Yayat, and Muhammad Ramdhan, "Pemetaan Tingkat Kerentanan Pesisir Wilayah Kota Pariaman", Jurnal Fakultas Perikanan dan Ilmu Kelautan Unpad, 2012.
Adger, W. Neil, et al., "Migration, Remittances, Livelihood Trajectories, and Social Resilience", Ambio: A Journal of the Human Environment 31.4. 2002.

Andayani, Anak Agung Istri, Edhi Martono, and Muhamad Muhamad, "Pemberdayaan Masyarakat Melalui Pengembangan Desa Wisata dan Implikasinya terhadap Ketahanan Sosial Budaya Wilayah (Studi Di Desa Wisata Penglipuran Bali)", Jurnal Ketahanan Nasional, 23.12015.

Chernovita, Hanna Prillysca, "Pemetaan Wilayah Risiko Bencana Banjir Kabupaten Kudus Berdasarkan Aspek Ancaman, Kerentanan, dan Kapasitas Berbasis Sistem Informasi Geografis", Disertasi, Program Studi Sistem Informasi FTI-UKSW, 2014.

Coakley, John, "National Territories and Cultural Frontiers: Conflicts of Principle in the Formation of States in Europe", West European Politics, Vol. 5, No. 4, 1982.

Deda, Andreas Jefri, and Suriel Semuel Mofu, "Masyarakat Hukum Adat dan Hak Ulayat di Provinsi Papua Barat Sebagai Orang Asli Papua Ditinjau Dari Sisi Adat dan Budaya: Sebuah Kajian Etnografi Kekinian", Jurnal Administrasi Publik, Vol. 11, No. 2, 2014.

Magis, Kristen, "Community Resilience: An Indicator of Social Sustainability", Society and Natural Resources, 23.5. 2010.

Marshall, Nadine, and Paul Marshall, "Conceptualizing and Operationalizing Social Resilience Within Commercial Fisheries in Northern Australia", Ecology and Society, Vol.12, No.1, 2007.

Pramono, Albertus Hadi, "Perlawanan atau Pendisiplinan? Sebuah Refleksi Kritis atas Pemetaan Wilayah Adat", Arsip Digital, 2014.

Safa'at, Rachmad, “Rekonstruksi Politik Hukum Ketahanan Pangan Berbasis 
Pada Sistem Kearifan Lokal (Studi Kasus Dinamika Perlindungan Hukum Hak Masyarakat Adat Tengger dalam Menuju Kedaulatan Pangan)", Disertasi Program Pascasarjana Undip, 2011.

Sukada, Soni dkk, "Pemetaan Hak-Hak Ulayat Orang Sumuri di Distrik Sumuri Kabupaten Teluk Bintuni”, Laporan Penelitian, Universitas Negeri Manokwari, Papua Barat, 2015

Suryawan, I. Ngurah, "Di Antara Ugatamee dan Injil: Transformasi Teologi-Teologi Pribumi di Tanah Papua", Islam Realitas: Journal of Islamic \& Social Studies, Vol. 2, No.1, Januari-Juni 2016.

Tim LPM UI, "Pemetaan Sosial Masyarakat Distrik Sumuri Kabupaten Teluk Bintuni", Laporan Penelitian, Lembaga Pengabdian Masyarakat Universitas Indonesia, 2014. 